\title{
Pengolahan limbah cair industri pelapisan logam dengan proses elektrokoagulasi secara kontinyu
}

\author{
Idral Amri*, Febri Awalsya, Irdoni \\ *Prodi Teknik Kimia, Fakultas Teknik, Universitas Riau \\ Kampus Binawidya Km 12,5 Simpang Baru, Pekanbaru \\ e-mail: *idral_amri@eng.unri.ac.id \\ Diterima: 16 September 2019/ Disetujui: 15 Mei 2020/ Dipublikasi online: 31 Mei 2020 \\ DOI: https://doi.org/10.22437/chp.v5i1.7650
}

\begin{abstract}
ABSTRAK
Limbah cair industri pelapisan logam berasal dari hasil pembilasan pada proses pelapisan dengan Krom (Cr), masih banyak terkandung zat berbahaya apabila langsung dibuang kelingkungan. Untuk itu perlu dilakukan pengolahan lebih lanjut dengan menggunakan elektrokoagulasi. Metode ini memiliki potensi penjernihan limbah cair pelapisan logam dan penurunan kandungan logam yang terkandung tanpa adanya penambahan koagulan. Tujuan dari penelitian ini untuk mengetahui penerapan metoda elektrokoagulasi untuk menetralkan $p H$, serta menurunkan kadar TSS dan Cr pada limbah dan untuk mengetahui pengaruh perubahan laju alir dan kuat arus untuk menetralkan pH, serta menurunkan kadar TSS dan Cr pada limbah. Parameter yang diuji meliputi pH, TSS (Total Suspended Solid), dan Cr. Proses elektrokoagulasi menggunakan listrik searah melalui elektroda. Reaktor elektrokoagulasi yang dipasangkan kabel ke power suplay kemudian disambungkan ke arus listrik dengan variasi kuat arus $(1,2 ; 1,6$; dan 2 A) dan variasi laju alir $(0,78 ; 1,32 ; 2,7 \mathrm{~L} /$ menit). Hasil penelitian didapat kondisi optimum pada kuat arus $2 \mathrm{~A}$ dan laju alir 0,78 L/menit dengan kenaikan $\mathrm{pH}$ dari 4,5 menjadi 6,6, penurunan TSS dari 3,2 menjadi 1,2 mg/L, penurunan $\mathrm{Cr}$ sebesar 82,4\% dari $1,5 \mathrm{mg} / \mathrm{L}$ menjadi $0,263 \mathrm{mg} / \mathrm{L}$.
\end{abstract}

Kata kunci: elektrokoagulasi, kuat arus, kontinyu, laju alir, limbah cair

\begin{abstract}
Electroplating industrial waste is coming from the rinsing processes on Chrome (Cr) electroplating, still having many harm contents when direct release to surrounding. So that need to do continuing processes with electrocoagulation method. This is the potential method to purifine the metal electroplating waste and reduction metal content without any coagulance. The aim of the research is determining applied electrocoagulation method to neutralize of $p H$ and also to decrease TSS (Total Suspended Solid) and Cr content of waste. The parameter tested covered pH, TSS and $\mathrm{Cr}$ contents. Electrocoagulation Process is using electrical direct current to electrode. Electrocoagulation Reactor is as connected by electric cables to power supply, then be connected to electric current with among of variations such as current $(1,2 ; 1,6 ; 2,0$ A) and variation of flowrate $(0,78 ; 1,32 ; 2,7 \mathrm{~L} /$ minute). The results of research found optimum condition at $2 \mathrm{~A}$ current and $0,78 \mathrm{~L} /$ minute of flowrate, with increasing the $\mathrm{pH}$ from 4,5 to 6,6 of $\mathrm{pH}$ scale, decreasing TSS from 3,2 to $1,2 \mathrm{mg} / \mathrm{L}$, percent removal of $\mathrm{Cr}$ is $82,4 \%$ from $1,5 \mathrm{mg} / \mathrm{L}$ to $0,263 \mathrm{mg} / \mathrm{L}$.
\end{abstract}

Keywords: continue, electrocoagulation, electric current, flowrate, liquid waste 


\section{PENDAHULUAN}

Semakin tumbuh dan berkembangnya industri-industri di Indonesia membantu peningkatan perekonomian dan kesejahteraan masyarakat Indonesia, tetapi disisi lain menimbulkan dampak yang kurang baik bagi lingkungan, yaitu adanya limbah yang dihasilkan, salah satu contohnya adalah limbah cair. Industri Pelapisan Logam dalam proses produksinya menghasilkan limbah cair. Sumber utama air limbah adalah larutan sisa proses elektroplating itu sendiri dan larutan pembilasan dari tiga tangki larutan dimana dengan proses kerja logam yang akan dilapisi dimasukkan ke dalam tangki-tangki yang berisi larutan asam dan garam logam kemudian dibilas dengan air (Gautama, 2011). Air pembilasan inilah yang menjadi sumber utama limbah cair.

Pembuangan langsung limbah dari proses elektroplating tanpa pengolahan terlebih dahulu ke lingkungan dapat menyebabkan pencemaran lingkungan. Cemaran tersebut dapat mencemari mikroorganisme dan lingkungannya baik dalam bentuk larutan, koloid, maupun bentuk partikel lainnya. Mengingat penting dan besarnya dampak yang ditimbulkan bagi lingkungan maka diperlukan suatu pengolahan terlebih dahulu sebelum efluent limbah tersebut dibuang ke lingkungan (Charlena, 2014). Dengan demikian perlu dilakukan proses penanganan limbah cair sehingga sesuai dengan baku mutu nya. Berdasarkan referensi yang ada, ada beberapa kemungkinan teknologi pengolahan limbah pelapisan logam, diantaranya koagulasi-flokulasi, elektrokoagulasi, dan pertukaran ion (Jauharoh, 2019).

Menurut peraturan Menteri Lingkungan Hidup Republik Indonesia Nomor 5 Tahun 2014, kandungan maksimum Total Suspended Solid (TSS) dan unsur Krom (Cr) dalam limbah Industri pelapisan yang diizinkan adalah $20 \mathrm{mg} / \mathrm{L}$ dan 0,5 $\mathrm{mg} / \mathrm{L}$, serta $\mathrm{pH}$ yang diizinkan adalah 6-9.

Menurut penelitian terdahulu, teknologi elektrokoagulasi, merupakan salah satu teknologi yang efektif dan efisien untuk pemurnian limbah industri pelapisan logam secara batch (Yudo dan Said, 2005), kemudian dikembangkan penelitian pemurnian air gambut yang mengandung ion logam (ferro) menggunakan system elektrokoagulasi secara kontinyu (Amri et al., 2018). Elektrokoagulasi merupakan salah satu metode yang dapat digunakan untuk menurunkan kadar TSS, Kandungan logam dan pH sesuai dengan Permen LH No.5 tahun 2014. Elektrokoagulasi ini merupakan proses koagulasi atau penggumpalan dengan 
tenaga listrik melalui proses elektrolisis untuk mengurangi atau menurunkan ionion logam dan partikel-partikel di dalam air. Untuk mengurangi pencemaran air, maka diperlukan pengolahan limbah terlebih dahulu sebelum limbah tersebut dibuang ke sungai. Prinsip dasar dari elektrokoagulasi adalah reaksi reduksi dan oksidasi (redoks). Dalam suatu sel elektrokoagulasi, peristiwa oksidasi terjadi di elektroda $(+)$ yaitu anoda, sedangkan reduksi terjadi di elektroda (-) yaitu katoda. Pada akhirnya terbentuk flokulan yang akan mengikat kontaminan maupun partikel-partikel dari air baku tersebut. Proses Elektrokoagulasi dikenal juga sebagai elektrolisis gelombang pendek (Wiyanto et al, 2014).

Tujuan dilakukannya penelitian ini adalah untuk mengetahui penerapan metoda elektrokoagulasi dapat digunakan untuk menurunkan kandungan logam Cr dan TSS serta menetralkan $\mathrm{pH}$ pada limbah cair industri pelapisan logam dan Mengetahui pengaruh perubahan laju alir dan kuat arus terhadap penurunan kadar TSS, kandungan logam $\mathrm{Cr}$ dan penetralan $\mathrm{pH}$ limbah industri pelapisan logam.

\section{METODOLOGI PENELITIAN}

\section{Bahan dan Peralatan}

Bahan-bahan yang digunakan dalam penelitian ini adalah Limbah cair industri pelapisan logam UPT. Riau Elektroplatting, Pekanbaru.

Alat-alat yang digunakan dalam penelitian ini, yakni: DC power supply, elektroda alumunium, wadah plastik, kertas saring, $\mathrm{pH}$ meter, dan AAS (Atomic Absorption Spectroscopy) merk Shimadzu AA - 6300 untuk mengetahui kadar logam $\mathrm{Cr}$ di Laboratorium Pengujian dan Analisa Kimia Universitas Riau. Rangkaian alat untuk proses pengolahan air dapat di lihat pada gambar 1. (Amri et al., 2018). 


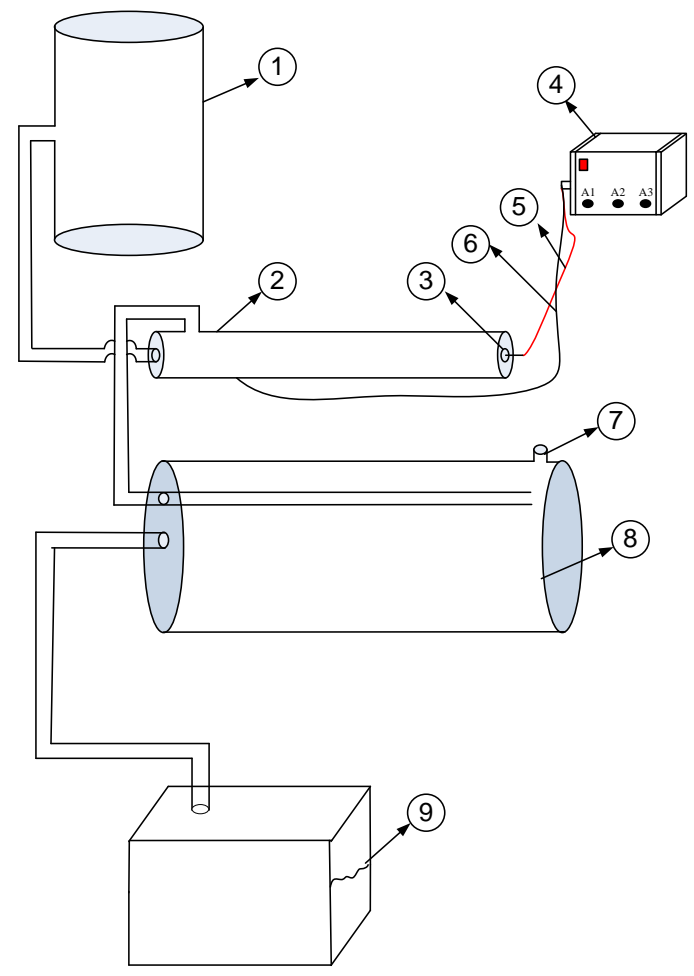

Keterangan :

1. Limbah Cair Industri Pelapisan Logam

2. Elektroda Luar

3. Elektroda Dalam

4. Power Supply

5. Kabel Merah (+)

6. Kabel Hitam (-)

7. Tempat Pembuangan Gas $\mathrm{H}_{2}$

8. Separator

9. Air Bersih Hasil Olahan

Gambar 1. Rangkaian alat proses elektrokoagulasi secara kontinyu

\section{Variabel Penelitian}

Variabel yang digunakan dalam penelitian ini terdiri dari variabel tetap dan variabel bebas. Variabel tetap pada penelitian ini yaitu volume sampel 5 liter, panjang elektroda 2 meter, tegangan $12 \mathrm{~V}$ dan jarak elektroda 0,5 inchi. Sedangkan variabel bebas pada penelitian ini yaitu variasi laju alir $(0,78 ; 1,32$;

2,78 L/menit) dan kuat arus $(1,2 ; 1,6$ dan $2 \mathrm{~A})$.

\section{Proses Elektrokoagulasi}

Limbah cair industri pelapisan logam yang telah di uji karakteristik awalnya di alirkan ke dalam reaktor melalui pipa innert. setelah itu Power Supply DC disambungkan ke arus listrik, dengan variasi kuat arus 1,$2 ; 1,6$ dan 2 A pada laju alir 0,$78 ; 1,32 ; 2,78 \mathrm{~L} /$ menit. Kemudian, sampel hasil di uji kandungan TSS secara gravitasi, $\mathrm{pH}$ Menggunakan pHmeter dan konsentrasi Cr didalam limbah menggunakan AAS.

\section{HASIL DAN PEMBAHASAN}

\section{Analisis Limbah Awal}


Analisis sampel awal bertujuan untuk memperoleh data karakteristik limbah sebelum dilakukan proses elektrokoagulasi. Berdasarkan Analisis bahan baku, maka diperoleh data sampel awal seperti tabel 1.

Tabel 1. Hasil Analisis Sampel Awal

\begin{tabular}{ccc}
\hline Parameter & Sampel Limbah Cair & Permen LH No.5 Tahun 2014 \\
\hline TSS & $3,2 \mathrm{mg} / \mathrm{L}$ & $20 \mathrm{mg} / \mathrm{L}$ \\
pH & 4,5 & $6-9$ \\
Konsentrasi Cr & $1,5 \mathrm{mg} / \mathrm{L}$ & $0,5 \mathrm{mg} / \mathrm{L}$ \\
\hline
\end{tabular}

\section{Variasi Laju Alir}

Konsentrasi Krom. Konsentrasi $\mathrm{Cr}$ pada sampel awal limbah cair yaitu sebesar 1,5 mg/L. konsentrasi Cr ini melebih baku mutu Permen LH No. 5 Tahun 2014 yang diizinkan tidak boleh melebihi dari 0,5 mg/L sehingga dilakukan lah proses elektrokoagulasi untuk menurunkan konsentrasi $\mathrm{Cr}$ yang terdapat pada limbah cair tersebut. Adapun hasil analisa konsentrasi $\mathrm{Cr}$ menggunakan AAS pada berbagai variasi laju alir ditampilkan pada Gambar 2.

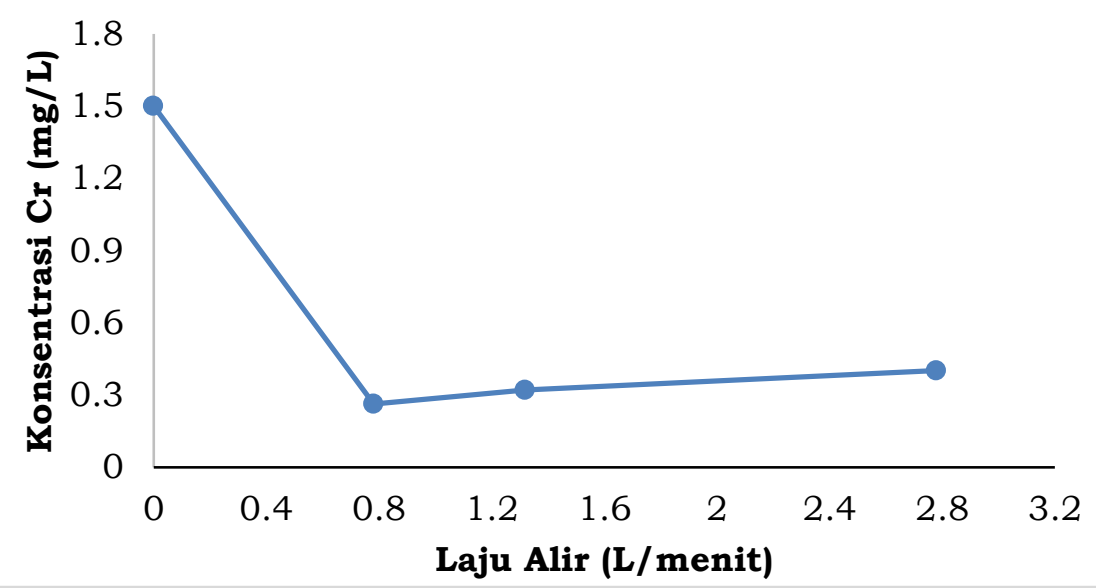

Gambar 2. Grafik Pengaruh Laju alir (L/menit) Pada Kuat Arus 2 A Terhadap Konsentrasi Cr Dalam Limbah Cair Pelapisan Logam

Pada proses elektrokimia, pada saat adanya arus listrik di anoda akan terjadi reaksi oksidasi terhadap anion (kutub negatif), anoda yang terbuat dari bahan alumunium akan mengalami reaksi oksidasi membentuk ion $\mathrm{Al}^{3+}$ dan akan mengikat $\mathrm{OH}-$ membentuk flok $\mathrm{Al}(\mathrm{OH})_{3}$ yang akan mengikat ion ion $\mathrm{Cr}$ pada limbah cair. Penyisihan kandungan logam terlarut akan semakin tinggi seiring terbentuknya $\mathrm{Al}(\mathrm{OH})_{3}$. Penyisihan $\mathrm{Cr}$ terjadi ketika semakin banyaknya ion $\mathrm{Al}^{3+}$ yang dihasilkan pada anoda dan membentuk flok $\mathrm{Al}(\mathrm{OH})_{3}$ yang berperan sebagai koagulan. Kemudian flok $\mathrm{Al}(\mathrm{OH})_{3}$ tersebut dapat mengikat senyawa organik dan 
logam logam yang terkandung dalam air (Saputra dan Farida, 2016). Berikut ini adalah mekanisme penyisihan $\mathrm{Cr}$ yang terjadi selama proses elektrokoagulasi.

$$
\begin{aligned}
& \text { Anoda }: \mathrm{Al}(\mathrm{s}) \rightarrow \mathrm{Al}^{3+}+3 \mathrm{e} \\
& \text { Katoda }: 2 \mathrm{H}_{2} \mathrm{O}(\mathrm{aq})+2 \mathrm{e} \rightarrow 2 \mathrm{OH}-+\mathrm{H}_{2} \\
& \text { Overall }: \mathrm{Al}^{3+}+3 \mathrm{H}_{2} \mathrm{O}(\mathrm{aq}) \rightarrow \mathrm{Al}(\mathrm{OH})_{3}(\mathrm{~s})+3 \mathrm{H}^{+}
\end{aligned}
$$

Proses elektrokoagulasi secara kontinyu ini mampu menurunkan konsentrasi $\mathrm{Cr}$ secara berturut turut, pada kondisi arus $2 \mathrm{~A}$, laju alir sampel 0,78L/menit; $1,32 \mathrm{~L} /$ dan 2,7 L/menit, sebesar 82,4\%; 78,6\% dan 73,2\%. Hal ini disebabkan semakin cepatnya laju alir air sampel maka waktu tinggalnya semakin singkat, sehingga ion-ion yang bereaksi semakin sedikit, hasil ini sesuai dengan penelitian yang dilakukan oleh (Nur dan Jatnika, 2014).

Total Suspended Solid (TSS). Salah satu parameter yang dianalisis dalam penelitian ini adalah TSS. Kadar TSS sampel awal sebesar 3,2 mg/L yang sudah memenuhi baku mutu PermenLH No.5 Tahun 2014. Hasil analisis TSS pada berbagai variasi laju alir ditampilkan pada Gambar 3.

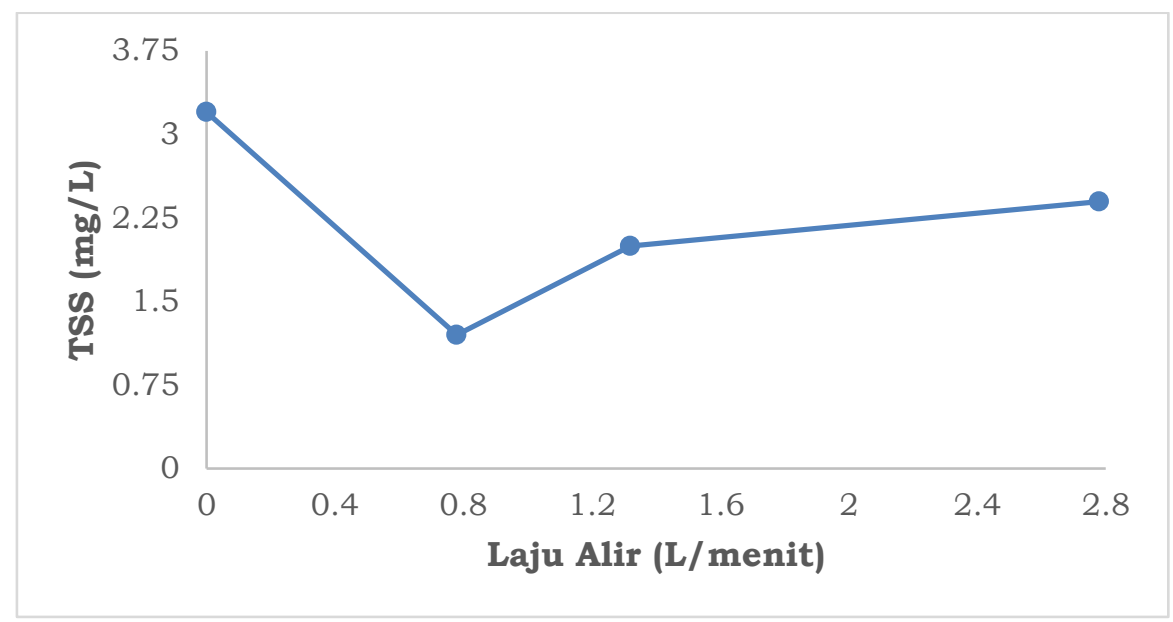

Gambar 3. Grafik Pengaruh Laju Alir (L/menit) Pada Kuat Arus 2 A Terhadap Perubahan TSS Dalam Limbah Cair Pelapisan Logam

Dalam penelitian ini, limbah cair pelapisan logam diberi perlakuan dengan besar laju alir yang bervariasi secara berurutan 0,78 L/menit ; 1,32 L/menit dan 2,7 L//menit dengan kuat arus $2 \mathrm{~A}$ dan waktu reaksi selama 10 menit menggunakan pipa aluminium berukuran 2 meter. Pada Gambar 3, dapat dilihat bahwa proses elektrokoagulasi secara kontinyu ini mampu menurunkan kadar TSS pada kondisi arus sebesar 2 A variable laju alir seperti tabel 2.

Dari tabel 2 kelihatan semakin besar laju alir, maka persen removal $\mathrm{Cr}$ juga semakin kecil, hal ini disebabkan semakin cepatnya laju alir sampel maka waktu 
reaksinya semakin singkat, sehingga ion-ion yang bereaksi semakin sedikit, penjelasan ini sesuai dengan konsep hukum Faraday. Dimana, semakin kecil waktu tinggal didalam reactor, maka massa logam yang terektrolisis juga semakin kecil, sehingga akan menyebabkan persen removalnya juga akan semakin kecil juga.

Tabel 2. Pengaruh Laju Alir terhadap \% Removal Senyawa Cr, pada Arus 2 A

\begin{tabular}{ccc}
\hline Laju Alir, L/menit & Konsentrasi Cr & \% Removal \\
\hline 0 & 3,2 & 0 \\
0,78 & 1,2 & 62,5 \\
1,32 & 2 & 37,5 \\
2,78 & 2,4 & 25 \\
\hline
\end{tabular}

pH. Penambahan asam klorida $(\mathrm{HCl})$ pada proses penghilangan karatan pada besi berakibat pada $\mathrm{pH}$ limbah cair yang dihasilkan. Hasil analisa pada sampel awal menunjukkan bahwa limbah bersifat asam dengan $\mathrm{pH}$ sebesar 4,5. Setelah dilakukan elektrokoagulasi dengan variasi laju alir, diperoleh hasil perubahan $\mathrm{pH}$ limbah seperti yang tercantum pada Gambar 4.

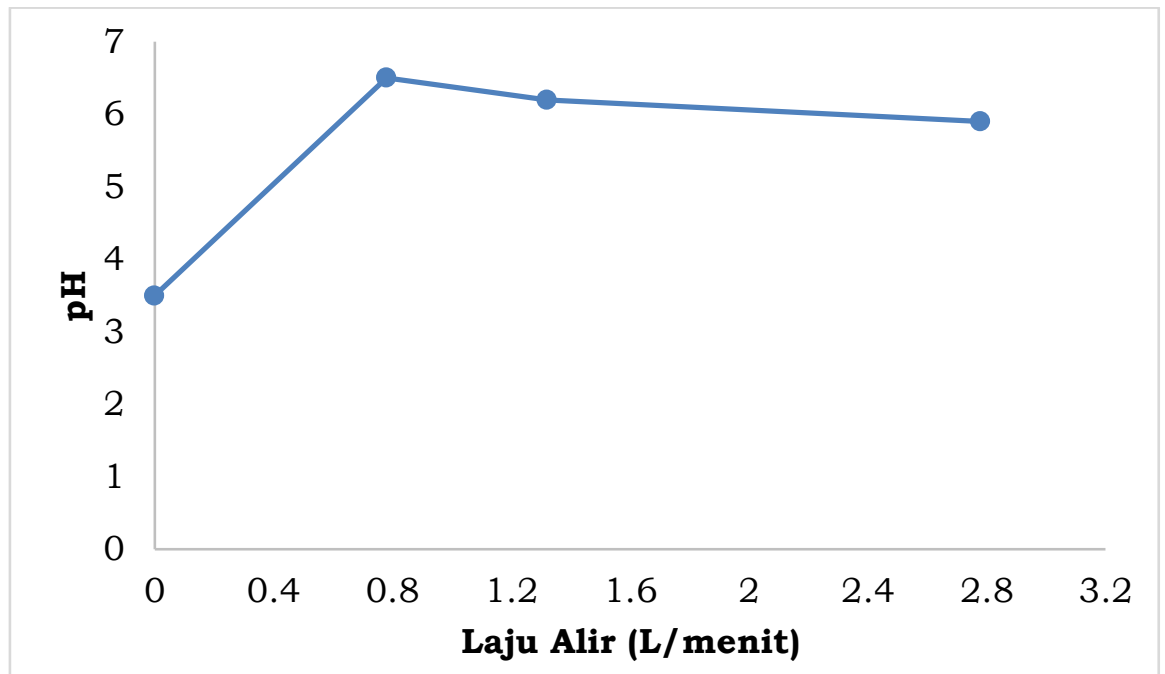

Gambar 4. Grafik Pengaruh Laju alir Pada Kuat Arus 2 A Terhadap pH Dalam Limbah Cair Pelapisan Logam

Gambar 4. menunjukkan semakin besar kecepatan alir yang diberikan akan mengakibatkan nilai pH meningkat dan semakin cepat laju alir sampel maka peningkatan nilai $\mathrm{pH}$ akan semakin turun mendekati $\mathrm{pH}$ netral air (7). Menurut (Yonna, 2017) pH larutan meningkat dan berada pada rentang interval $\mathrm{pH}$ netral, yaitu mendekati $\mathrm{pH}$ air, karena selama proses elektrokoagulasi terjadi pembentukan $\mathrm{H}_{2} \mathrm{O}$, dari reaksi $\mathrm{H}^{+}$dan $\mathrm{OH}^{-}$dan gas $\mathrm{H}_{2}$. 


\section{Variasi Kuat Arus}

Konsentrasi Krom (Cr). Konsentrasi Cr pada sampel awal limbah cair yaitu sebesar 1,5 mg/L. Konsentrasi Cr ini melebih baku mutu PermenLH No.5 Tahun 2014 yang diizinkan tidak boleh melebihi dari $0,5 \mathrm{mg} / \mathrm{L}$ sehingga perlu dilakukan proses elektrokoagulasi untuk menurunkan konsentrasi $\mathrm{Cr}$ yang terdapat pada limbah cair tersebut. Adapun hasil analisa konsentrasi $\mathrm{Cr}$ menggunakan AAS pada berbagai variasi kuat arus ditampilkan pada Gambar 5.

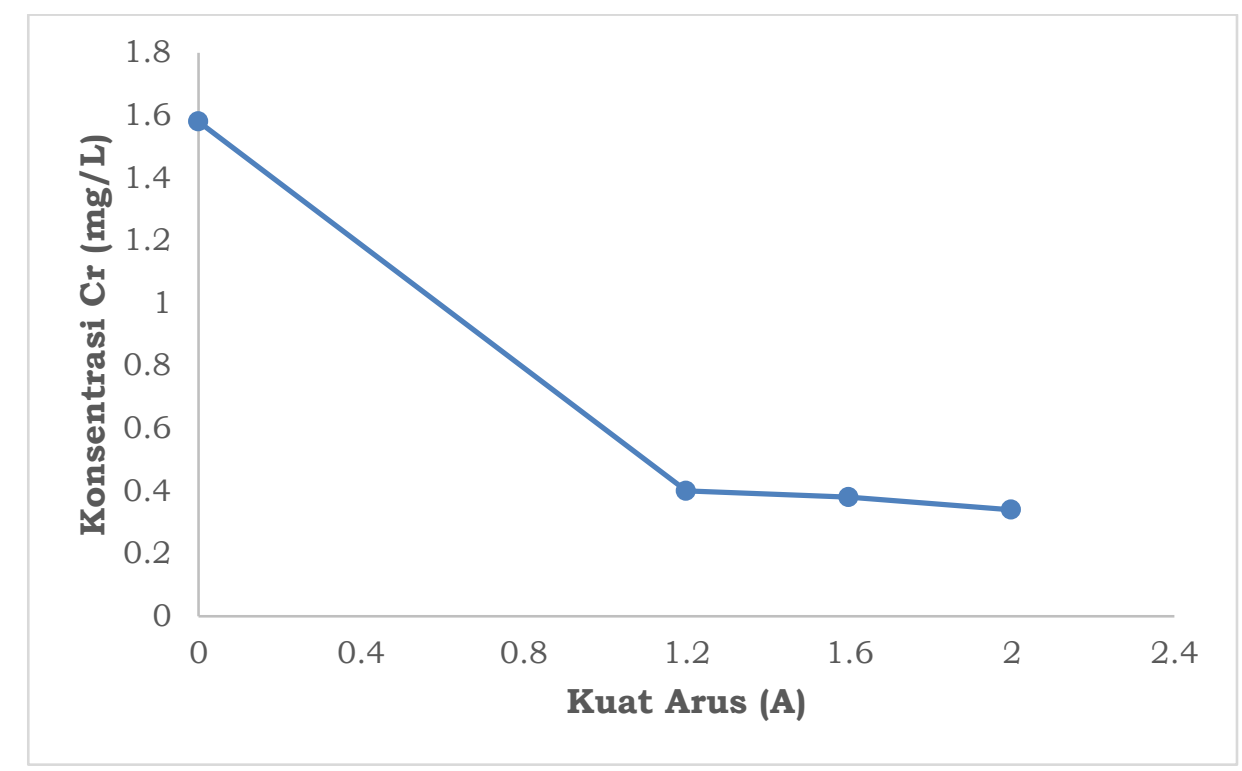

Gambar 5. Grafik Pengaruh Kuat Arus Pada Laju Alir 0,78 L/Menit terhadap Penurunan Konsentrasi Cr dalam Limbah cair pelapisan logam.

Berdasarkan hasil percent removal, ketiga variasi kuat arus (1,2 A; 1,6 A; dan 2 A) pada laju alir 0,78 L/menit memiliki percent removal sebesar 73,4\% ; 76,5\% ; dan $82,4 \%$. Hasil tersebut menunjukkan adanya pengaruh kuat arus terhadap percent removal logam Cr. Menurut (Yonna, 2017) bahwa penyisihan kandungan logam terlarut akan semakin tinggi seiring terbentuknya $\mathrm{Al}(\mathrm{OH})_{3}$. Penyisihan $\mathrm{Cr}$ terjadi ketika semakin banyaknya ion $\mathrm{Al}^{3+}$ yang dihasilkan pada anoda dan membentuk flok $\mathrm{Al}(\mathrm{OH})_{3}$ yang berperan sebagai koagulan. Kemudian flok $\mathrm{Al}(\mathrm{OH})_{3}$ tersebut dapat mengikat senyawa organik dan logam logam yang terkandung dalam air (Saputra dan Farida, 2016).

Total Suspended Solid (TSS). Kadar TSS sampel awal sebesar 3,2 mg/L yang sudah memenuhi baku mutu PermenLH No.5 Tahun 2014. Hasil analisis TSS pada berbagai variasi kuat arus ditampilkan pada Gambar 6. 


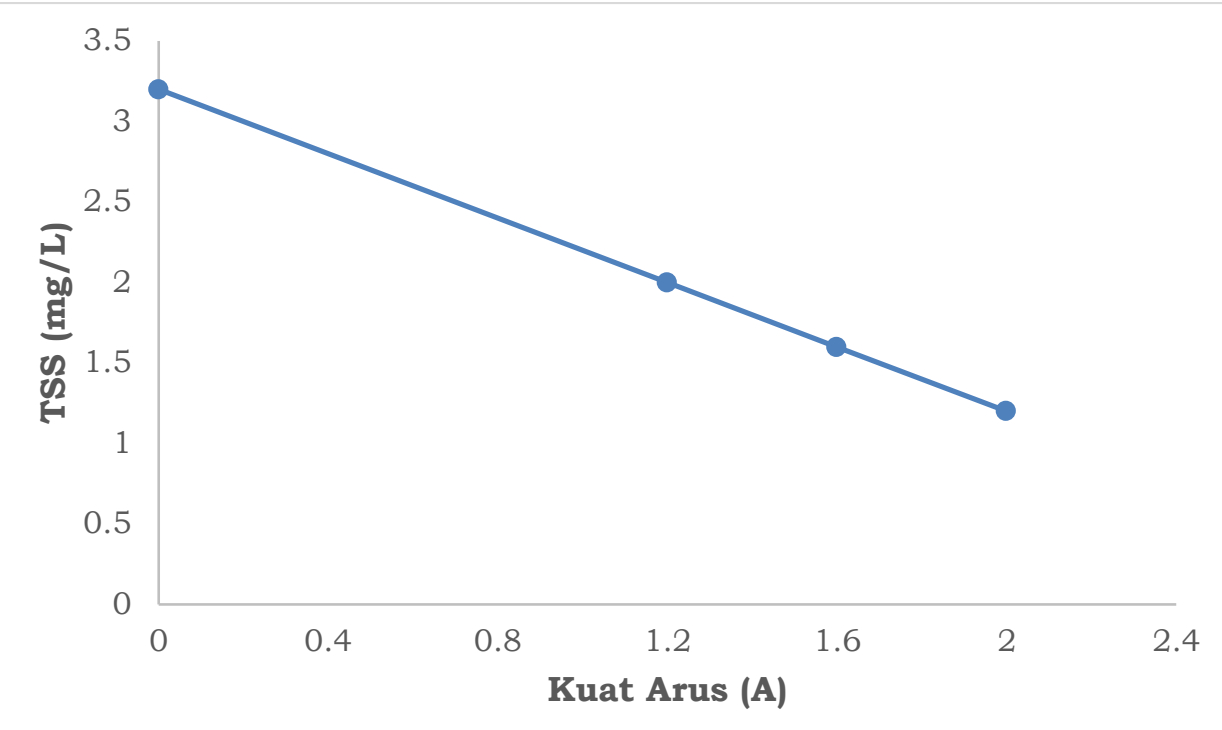

Gambar 6. Pengaruh Kuat Arus Pada Laju Alir 0,78 L/Menit Terhadap Perubahan TSS Dalam Limbah Cair Pelapisan Logam

Penurunan kadar TSS disebabkan oleh adanya oksidasi logam alumunium menjadi ion $\mathrm{Al}^{3+}$ di katoda serta pembentukan ion $\mathrm{OH}^{-}$di anoda. Ion $\mathrm{Al}^{3+}$ dan $\mathrm{OH}^{-}$ selanjutnya akan membentuk $\mathrm{Al}(\mathrm{OH})_{3}$ yang bertindak sebagai koagulan. Koagulan akan mengikat padatan tersuspensi yang terdapat pada limbah cair sehingga terbentuklah flok. Flok yang telah terbentuk akan terangkat ke permukaan oleh hidrogen yang terbentuk di katoda. Proses penurunan TSS dapat difahami karena TSS adalah polutan yang berada dalam bentuk tersuspensi. Bila suatu materi tersuspensi maka material tersebut berbentuk solid dengan ukuran tertentu. Material solid ini dapat dengan mudah teradsorbsi ke dalam koagulan $\mathrm{Al}(\mathrm{OH}) \mathrm{x}$ atau teradsorbsi ke dalam gelembung udara. Hasil adsorbsi ini akan terpisahkan ke atas (terflotasi) sehingga terjadi penurunan konsentrasi TSS di dalam air limbah (Hanum, 2015). Pada gambar 7 berikut, menjelaskan proses elektrokoagulasi yang terjadi pada reaksi elektrolisis. 


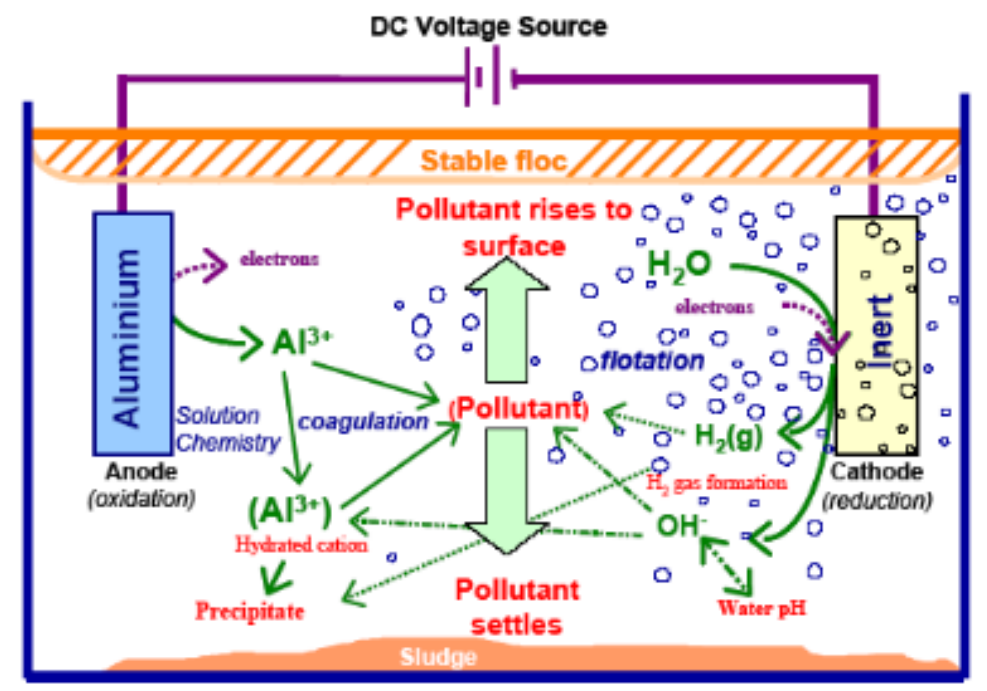

Gambar 7. Mekanisme Elektrokoagulasi (Holt, 2003)

pH. Peningkatan $\mathrm{pH}$ dipengaruhi oleh besarnya arus yang diberikan. Peningkatan $\mathrm{pH}$ tersebut disebabkan oleh adanya pelepasan ion $\mathrm{OH}$ - di katoda. Masing-masing kuat arus menghasilkan perubahan $\mathrm{pH}$ yang berbeda, seperti yang terlihat pada Gambar 8.

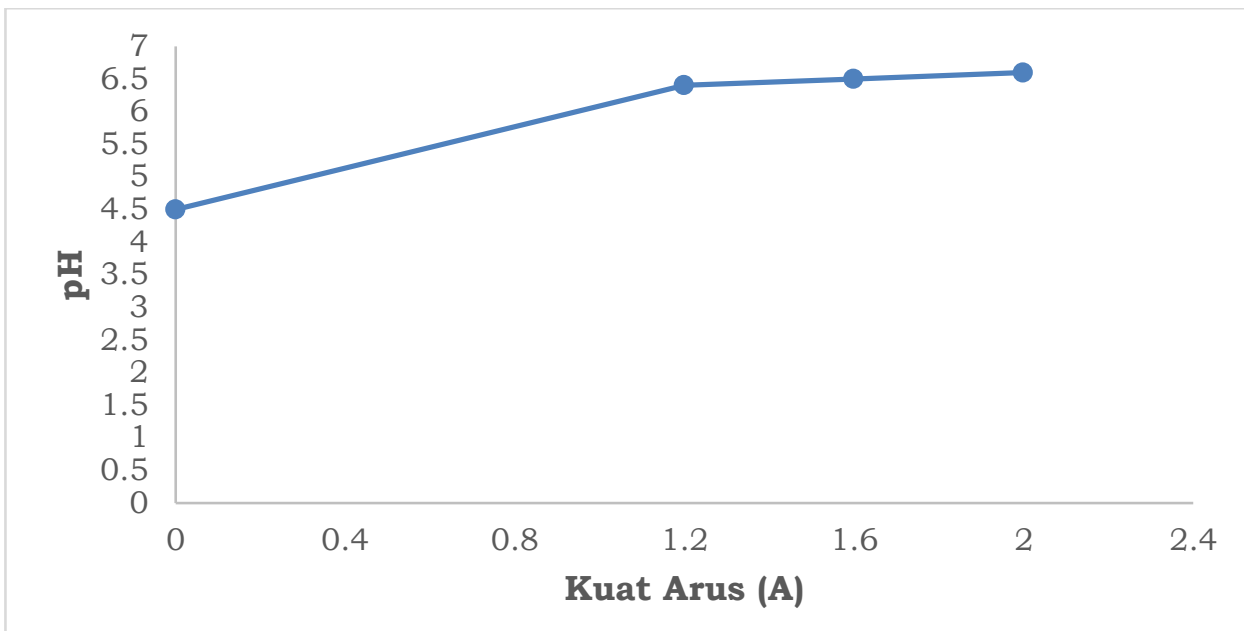

Gambar 8. Pengaruh Kuat Arus Pada Laju Alir 0,78 L/Menit Terhadap pH Dalam Limbah Cair Pelapisan Logam

Berdasarkan data pada Gambar 8. dapat diketahui bahwa perubahan $\mathrm{pH}$ tertinggi terjadi pada kuat arus 2A, yaitu 6,6 skala dari 14 . Sedangkan perubahan pH terendah terjadi pada kuat arus 1,2 A yaitu 6,4 skala. Rendahnya perubahan $\mathrm{pH}$ pada kuat arus 1,2 A disebabkan oleh arus yang terlalu kecil sehingga gas hidrogen yang dihasilkan menumpuk pada area sekitar elektroda. Akibatnya, ion $\mathrm{OH}-$ akan langsung terangkat ke permukaan. 


\section{KESIMPULAN}

Kesimpulan dari hasil penelitian elektrokoagulasi ini, mampu menurunkan kadar TSS, kandungan logam Cr didalam limbah cair pelapisan logam dan juga mampu menetralkan $\mathrm{pH}$. Perubahan laju alir dan kuat arus pada proses elektrokoagulasi ini didapatkan kondisi terbaik pada kuat arus 2 A dan laju alir 0,78 L/menit dengan kenaikan pH dari 4,5 menjadi 6,6 , penurunan TSS dari 3,2 $\mathrm{mg} / \mathrm{L}$ menjadi 1,2 $\mathrm{mg} / \mathrm{L}$. Penurunan konsentrasi $\mathrm{Cr}$ dengan efisiensi sebesar $82,4 \%$ dari $1,5 \mathrm{mg} / \mathrm{L}$ menjadi $0,263 \mathrm{mg} / \mathrm{L}$ dan hasil ini sudah sesuai dengan standar PermenLH No. 5 Tahun 2014. Metode ini diharapkan bisa diterapkan kepada semua limbah cair yang ada, sebagai solusi alternative pengolahan limbah cair yang murah dan efektif.

\section{UCAPAN TERIMAKASIH}

Penulis menyampaikan terimakasih kepada perusahaan pelapisan logam di Kulim, Pekanbaru, Riau, Jurusan Teknik Kimia Universitas Riau dan semua pihak yang telah memberikan masukan dan arahan serta bantuan dalam menyelesaikan penelitian ini.

\section{DAFTAR PUSTAKA}

Charlena. 2014. Pencemaran Logam Berat Timbal (Pb) dan Cadnium (Cd) pada Sayur-sayuran. Tesis Program Magister Institut Pertanian Bogor. Bogor.

Fitria, D., 2017, Penurunan Warna dan Zat Organik Air Gambut dengan Cara Two Staged Coagulation, Digital Library ITB, Bandung.

Gautama, P. 2011. Mengenal Cara Pelapisan Logam: Bagian 1. http://www.infometrik.com/2009 /08/pelapisan-logam-bagian-1/. Diakses pada tanggal 25 Januari 2019.

Hanum, F., 2015, Aplikasi Elektrokoagulasi Dalam Pengolahan Limbah Cair Pabrik Kelapa Sawit. Jurnal Teknik Kimia USU, 4 (4).

Holt, P.K., 2003. Electrocoagulation: unravelling and synthesising the mechanisms behind a water treatment process, PhD thesis, Faculty of Engineering, The University of Sydney

Amri, I., Azis, A., Drastinawati, 2018, Effect of direct Electric Current on Contaminants Removal from the Peat Water with Continuous System, IOP Cong. Series: Materials Science and Engineering 345, 012045

Jauharoh, A.H., 2019, Perencanaan Instalasi Pengolahan Air Limbah (IPAL) pada Industri Elektroplating (Studi Kasus Kegiatan Elektroplating X) di Yogyakarta. Tugas Akhir. Program Studi Teknik Lingkungan, Fakultas Teknik Sipil dan Perencanaan. Universitas Islam Indonesia. Yogyakarta 
Kashefi, M., 2014, Efficiency Evaluation of Electrocoagulation Process For Removal of Chromium From Municipal and Industrial Water, Indian J.Sci. Res. 7: 1258-1268.

Mollah, M. Y. A, Robert, S., \& Jose, R.P., 2009, Fundamental Present and Future perspectives of Elektrocoagulation. Journal of Hazardous Material, B114: 199-21.

Nasution M A. 2011, Electrocoagulation of Palm Oil Mill Effluent as Wastewater Treatment and Hidrogen Production Using Electrode Aluminium. J. Environ, Qual. 49: 1332-1339

Pahlevi, M. R., 2009, Analisa Kadar Besi (Fe) dan Mangan (Mn) dari Air Gambut Setelah Dijernihkan dengan Penambahan Tulang Ayam, Tesis Program Magister Universitas Sumatera Utara.

Peraturan Menteri Lingkungan Hidup Republik Indonesia Nomor 5 Tahun 2014 Tentang Baku Mutu Air Limbah.

Prabowo, A. dan H. B. Gagah, 2012, Pengolahan limbah cair yang mengandung minyak dengan proses elektrokoagulasi dengan elektroda besi. Jurnal teknologi kimia dan industri, 1(1): 352-355.

Purwanto dan H. Syamsul, 2012, Teknologi Industri Elektroplating. Badan Penerbit UNDIP, Semarang.

Saputra, E. dan H. Farida, 2016, Pengaruh jarak antara elektroda pada reactor elektrokoagulasi terhadap pengolahan effluent limbah cair pabrik kelapa sawit. Jurnal Teknik Kimia USU, 5(4).

Siringgo-ringgo, E., 2012, Penggunaan Metode Elektrokoagulasi Pada Pengolahan Limbah Industri Penyamakan Kulit Menggunakan Alumunium Sebagai Sacrificial Elektrode. Jurnal Sains dan Teknologi Kimia.

SNI 06-6989.11, 2004, Cara Uji Derajat Keasaman (pH) dengan Menggunakan pH Meter

SNI 06-6989.3. 2004, Cara Uji Padatan Tersuspensi Total (Total Suspended solid, TSS) secara Gravimetri.

Surdia, T., 2013, Teknik Pengocoran Logam. Cetakan Ke-6 PT. Pradnya Paramitha. Jakarta

Wiyanto, E., Budi, H., Amelia, A., Rudy, P., Julita. dan Mario, S.K., 2014. Penerapan elektrokoagulasi dalam proses penjernihan limbah cair. Jurnal Ilmiah Teknik Elektro Trisakti, 12(1):19-36.

Yonna, Y., Shinta, E., dan Ivnaini, A., 2017, Metode Elektrokoagulasi untuk Mengolah Limbah Cair Batik di Unit Kegiatan Masyarakat Rumah Batik Andalan PT. Riau Andalan Pulp and Paper (RAPP).

Yudo, S. dan Said, N.I, 2005, Pengolahan Air Limbah Industri Kecil Pelapisan Logam, JAI 1(1):17-29. 